\title{
Specificity in Music-Pedagogical Training Future Music Teacher's to Conducting Woodwind Ensemble
}

\author{
Wang Zixi \\ Postgraduate student (China) \\ Dragomanov National Pedagogical University (Kyiv, Ukraine)
}

\begin{abstract}
The research looked for new ways to improve the management of ensembles and to formulate the readiness of the future leader for the educational process. Students' readiness for professional activity is presented as a complex personal formation. It covers a set of pedagogical influences aimed at different aspects of individual activity. They include mental processes and emotional-volitional reactions that regulate the degree of human activity, motives for its behavior; their awareness creates favorable conditions for the effective formation of the state of "readiness". In the future, the students' organizational skills will depend on the artistic, creative and pedagogical results, which are of particular importance for the conductor of the ensemble. In order to complete the rehearsal task, the conductor must carry out considerable preliminary organizational work. The analysis of its organizational activity makes it possible to distinguish such areas as: pedagogical, artistic, performing, figurative-content and technical.
\end{abstract}

Keywords: music teacher, music-pedagogical training, ensemble, wind instruments.

Актуальність дослідження. Підготовка майбутнього керівника в різних галузях науки розглядається під певним кутом зору. Якщо, скажімо, розглядати категорію «готовність»у психологічному аспекті, то передусім головною буде мотиваційна

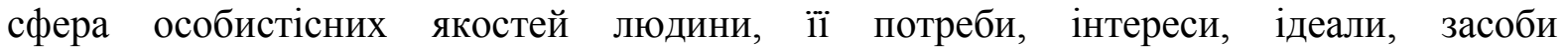
самовираження. При соціологічному аспекті найістотнішим $є$ дослідження «готовності» не лише як одного 3 компонентів психологічної структури, а й середовища. Останнє безпосередньо впливає на суб'єкт, його діяльність, мотивацію поведінки, в ньому розвивається якісний напрямок. Педагогічний підхід здебільшого включає аналіз навчально-виховного процесу та визначення його ролі у формуванні особистості. Таким чином, ці три аспекти - психологічний, соціологічний i педагогічний - $є$ важливими чинниками формування готовності, що створює передумови до керування ансамблями.

Актуальність нашого дослідження полягає у пошуку нових шляхів удосконалення керування ансамблевими колективами та формування готовності майбутнього керівника до навчально-виховного процесу. Це передбачає розв'язання поставленої проблеми в педагогічному аспекті, адже підготовка студентів до самостійної музично-педагогічної діяльності вимагає нової стрижневої якості - 
професійної готовності. Вона виховується завдяки цілеспрямованим зусиллям викладачів, які використовують певну програму та систему знань із теорії i закономірностей педагогічного процесу, а також врахуванню суті, внутрішньої структури, місця і ролі духового колективу в житті суспільства, розкриттю законів його становлення в сучасних умовах.

Виклад основного матеріалу. Оскільки категорія «готовність» в інших аспектах може бути логічним доповненням до розуміння іï як теоретичної передумови керування ансамблями, виникає потреба ширше розглянути це поняття.

Цікавим щодо цього, на нашу думку, є трактування готовності до певної діяльності, яке належить Н. Левітову [5], і визначається як психічний стан особистості (короткочасний або тривалий), що залежить від індивідуальних особливостей людини та умов, за яких відбувається діяльність суб'єкта.

Інший підхід до розуміння компонентів «готовності» пропонує К. ДурайНовакова. Вона розглядає структуру останньої в безпосередньому зв'язку із удосконаленням психічних процесів, необхідних для успішної діяльності вчителя. На переконання дослідниці, важливими елементами «готовності» $\epsilon$ також розвиток професійної спрямованості, ознайомлення 3 професією, професійне виховання, самовиховання і самовизначення $[1 ; 6 ; 7 ; 9 ; 11 ; 12 ; 13]$.

Отже, на думку згаданих вище дослідників, готовність студентів до професійної діяльності - складне особистісне утворення. Воно охоплює комплекс педагогічних впливів, спрямованих на різні сторони індивідуальної діяльності. Вони включають психічні процеси та емоційно-вольові реакції, що регулюють ступінь активності людини, мотиви її поведінки; усвідомлення їх створює сприятливі умови для ефективного формування стану «готовності».

Принагідно зауважимо, що інший автор - В. Крутецький - розуміє «готовність» як синтез властивостей особистості, що визначають їі здатність до діяльності. До них вчений відносить: низку характерологічних рис і стійких інтелектуальних почуттів; певний фонд знань, умінь і навичок у відповідній галузі; психологічні особливості розумової сфери, що визначаються вимогами до конкретної діяльності [4].

Варто звернутись і до концепції Л. Кондрашової. Вона досліджує механізм становлення професіоналізму студентів і намагається розкрити складні зв'язки між 
професійними установками, переконаннями i діяльністю та інтелектуальними, емоційно-вольовими і мотиваційними компонентами підготовки структури «готовності». За висновком ученої серед найважливіших якостей, які потрібно формувати в студентів, є організаторські здібності. Саме вони - першооснова створення та діяльності будь-якого колективу [3].

Також від рівня сформованості у студентів організаторських умінь залежатимуть в майбутньому художньо-творчі і педагогічні результати, що має для керівника ансамблевого колективу виняткове значення. Щоб виконати репетиційне завдання, керівник повинен здійснити значну попередню організаційну роботу. Аналіз його організаторської діяльності дає змогу виділити такі напрямки, як: 1) педагогічний; 2) художньо-виконавський; 3) образно-змістовний; 4) технічний.

Надамо характеристику згаданим напрямкам.

При педагогічній організащџї керівник повинен уміти визначити на основі ідеальної моделі кінцеву мету колективу та етапи їі реалізації.

Своєю чергою, художньо-виконавська організащія передбачає забезпечення нормального творчого процесу, вдумливу роботу над твором. Цей вид організаторської діяльності вимагає від майбутнього керівника великого емоційного напруження, органічного поєднання емоційного піднесення з високим інтелектуальним рівнем.

Образно-змістовний напрямок - це методика репетиційних занять та концертних виступів, приведення в дію відповідних засобів, визначення шляхів реалізації поставленої мети, що охоплює такі поняття, як організація виконання твору, розміщення учасників, методика роботи над оркестровою партією, художньо-технічні прийоми творчого процесу.

Технічна організація передбачає вирішення питань, не пов'язаних із творчо-виконавською діяльністю. Ії мета полягає в організаційно-педагогічному забезпеченні навчально-творчої діяльності ансамблю.

Отже, без глибоких знань та умінь правильно побудувати роботу в цих напрямках, що $є$ елементом готовності студентів до такої діяльності, практично неможливо, а також важко розраховувати на успіх будь-якого творчого колективу та його керівника. 
Практика показує, що організаторський аспект часто $є$ визначальним при формуванні творчого обличчя колективу. Тому до рівня організаторських умінь студентів (майбутніх керівників оркестрових колективів) потрібно ставити високі вимоги, особливо у плані створення духових ансамблів та керування ними. Слід також постійно, наполегливо i послідовно вдосконалювати організаторські здібності, збагачувати свою роботу новими прийомами, що врешті-решт забезпечує динаміку і перспективу розвитку колективу, його мистецьке та художньо-виконавське зростання.

Як вважає А. Каргін [2], існують різні типи керівників: 1) авторитарний; 2) ліберальний; 3) демократичний. Авторитарний тип відзначається сухістю, суворим ставленням до підлеглих. Такий керівник здатний затискувати ініціативу, чинити психологічний тиск на колектив чи окрему людину, підвищувати голос, гримати. Відомий психолог К. Платонов [8] характеризує авторитарний стиль як діяльність керівництва, яка «грунтується на авторитеті керівника. Авторитарний стиль керівника легко переростає в командування і прояв волюнтаризму - зайвого нав'язування своєї волі там, де без цього можна обійтися».

У специфічних умовах духового ансамблю, де все будується на засадах добровільності й інтересі учасників, авторитарний стиль керівника заважає взаєморозумінню й виробленню потрібного тону при спілкуванні, не враховує особливостей поведінки і діяльності дітей у даній сфері. Нерідко учасники на знак незгоди з методами керівництва такого наставника залишають колектив.

Ліберальний керівник відрізняється протилежними. Його вплив на колектив є мінімальним. Він малопомітний серед учасників, діє найчастіше через прохання або умовляння, не виявляючи достатньої твердості й послідовності. Може залишити поза увагою порушення, невиконання учасником свого завдання. Він не є офіційним лідером ансамблевого колективу, хоча від авторитету керівника залежить дуже багато, передусім його вміння забезпечити нормальну і змістовну роботу кожного учасника.

Керівникові демократичного типу властиве уміння впливати на людину через неформальну групу і колектив. Його авторитет грунтується на таких різнопланових якостях, як м’якість і вимогливість, поступливість і непримиренність. Він може вимагати і просити, карати і підтримувати, тобто демократичний стиль керівника 
відрізняється широтою і гнучкістю прийомів та методів роботи і ставленням до колективу.

3 наведених характеристик видно, що найбільше до керування ансамблевим колективом придатний керівник демократичного типу. Однак це не означає, що 3 колективом не можуть працювати керівники авторитарного або ліберального типів. Але в цьому разі вони мають враховувати особливості керівництва інструментальними ансамблями, постійно працювати над собою, виховувати якості демократичного типу керівників, наполегливо оволодівати різними методами роботи.

Перелічені вище психологічні якості і типи керівників потрібно враховувати при підготовці студентів до керування музичними колективами. Крім того, у вищих навчальних закладах слід також розвивати специфічні психологічні риси майбутнього вчителя під час роботи в конкретному виді творчої діяльності.

Здійснюючи репетиційну i концертну роботу, майбутній керівник інструментального ансамблю вирішує також педагогічні завдання. Відтак його спеціальна підготовка у ВНЗ має поєднуватися з набуттям різнобічних педагогічних знань. Педагогічна майстерність керівника ансамблевого колективу являє собою сукупність об'єктивних (психолого-педагогічних), суб'єктивних (культурноособистісних) факторів, що включають знання з педагогічної діяльності, основних іiі форм, методів, засобів, соціально-психологічних особливостей учасників ансамблю. Іншими словами, це набуття відповідних умінь і навичок, необхідних для всебічного виявлення себе як спеціаліста, здатного вирішувати організаційні, педагогічні і художньо-творчі завдання колективу.

Відповідно до сучасного бачення підготовки студентів до керування ансамблями доцільно виділити такі напрямки майбутньої професійної діяльності: 1) методичний, включає найважливіші аспекти професії керівника, якому передусім доводиться розпочинати діяльність з організації колективу, створення органів самоврядування, шукати ефективні форми і методи проведення репетиційних занять. Потрібно враховувати важливі методичні основи, оскільки керування ансамблевим колективом в позашкільних закладах відрізняється від керування професійним. Робота має грунтуватися на зацікавленні учасників творчою діяльністю і включати проведення репетицій, організацію навчально-виховної діяльності, залучення нових учасників 
тощо. 2) Психолого-педагогічний. Музично-педагогічна діяльність із ансамблевим колективом вимагає постійного зацікавлення учасників, врахування їхніх вікових інтересів і здібностей. Для ефективної роботи та досягнення поставленої мети доводиться використовувати всі можливі засоби психолого-педагогічного впливу на особистість учасників. Цей напрямок особливо актуальний при роботі 3 творчим колективом, адже поряд із виконанням функцій музиканта та диригента керівник повинен бути також педагогом і психологом, що сприятиме зростанню його професійного та морального авторитету. 3) Музичний. Навчання учасників гри на інструменті є дуже важливим для керівника, бо від результатів виконавської діяльності безпосередньо залежить і «закріпленість» учасників у колективі. 4) Діагностикопрогностичний містить діяльність, пов'язану із вивченням об'єкта педагогічного впливу, тобто ансамблевого колективу і кожного з його учасників, що дає можливість визначити оптимальні шляхи і методи виховного впливу. За В. Соловйовим, надзвичайно важливим є вміння виявити музичні здібності учасників і нахили до певного виду музичної діяльності, вивчити особливості учасника, інтереси і мотиви його діяльності.

3'ясувавши початковий рівень підготовки учасників колективу, керівник ставить перед собою цілі і завдання діяльності, накреслює шляхи і методи їхньої реалізації. Пізніше він переходить до планування педагогічного процесу в колективі, під час якого визначає етапи і послідовність педагогічних дій, вибирає репертуар, який відповідав би навчальній програмі. Важливою умовою діяльності керівника та дотримання належного рівня його «готовності» $є$ вивчення педагогічного досвіду кращих керівників, використання передової методики роботи з духовими колективами та методів педагогічного впливу.

Аналіз професійно-педагогічної діяльності, пов'язаної 3 керуванням інструментальним ансамблем, показав, що поставлені творчі завдання, які доводиться вирішувати керівнику, буде реалізовано за умови сформованої готовності виконувати певну систему дій. Умовно останні можна звести до чотирьох напрямків: методичний, психолого-педагогічний, музичний та діагностико-прогностичний.

Висновки. Підсумовуючи треба відзначити, що готовність студентів до керування інструментальними ансамблями формується поряд з умінням виховувати в 
учасників відчуття логічного співвідношення у звучанні усіх партій. Адже незалежно від оркестрового викладу музичної тканини твору іiі голоси, мелодичні лінії, гармонічний супровід завжди перебувають у нерозривному співвідношенні. При переході мелодії від однієї групи до іншої учасники ансамблю повинні знати, провідну чи допоміжну роль вони виконують у цьому разі. Необхідно навчити кожного слухати, від якої групи інструментів переходить мелодія чи фраза, створюючи єдиний цілісний образ у виконуваному музичному творі.

Таким чином, тільки знання специфічних особливостей музично-педагогічної діяльності дає можливість визначити умови вдосконалення підготовки студентів до керування інструментальним ансамблем. Здобуті у ЗВО вміння і навички забезпечують впровадження нових форм і методів роботи в ролі керівника ансамблевого колективу, а це, своєю чергою, сприятиме підвищенню естетичного і художнього рівня його учасників.

\section{References}

1. Duraj-Novakova K. I. Formuvannya profesijnoyi gotovnosti studentiv do pedagogichnoyi diyalnosti [Formation of students' professional readiness for pedagogical activity]: avtoref. dis. na zdobuttya nauk. stupenya kand. ped. nauk: 13.00.01. Moscow, 1983. $24 \mathrm{p}$.

2. Kargin A. S. Vihovna robota $v$ samodiyalnomu vihovnomu kolektivi [Educational work in an amateur educational team]. Moskva: Prosveshenie, 1984. 224 p.

3. Kondrashova L. V. Teoreticheskie osnovy vospitaniya nravstvenno-psihologicheskoj gotovnosti studentov pedagogicheskogo instituta k professionalnoj deyatelnosti [Theoretical Foundations of Upbringing in students of Pedagogical Institute Moral and Psychological Readiness for Professional Activities]: dis. ...doktor. ped. nauk: 132.00.01. Moscow, 1989. $363 \mathrm{p}$.

4. Kruteckij V. A. Psihologiya matematicheskih sposobnostej [Psychology of mathematical abilities]. Moscow, 1988.

5. Levitov N. D. O psihologicheskih sostoyaniyah cheloveka [About the psychological state of man]. Moscow, 1964. 344 p.

6. Pet'ko L.V. Formation of professionally oriented foreign language teaching environment in the terms of university for students of Music Art specialty (on illustration of a poem «The Spider and the Fly» by Mary Howitt. Scientific notes of the Berdyansk State Pedagogical University. Pedagogical sciences: collection of scientific articles. Issue 1. Berdyansk: FO-P Tkachuk O.V., 2016. P. 184-190.

7. Pet'ko L.V. Shljahy formuvannja inshomovnoi' sociokul'turnoi' kompetencii' studentiv mystec'kyh special'nostej VNZ u procesi fahovoi' pidgotovky [The Ways of Formation of Foreign Language Socio-Cultural Competence of Students of Music- 
Pedagogical Specialties in Higher School in the Process of Professional Teaching]/ Problemy pidgotovky suchasnogo vchytelja: zb. nauk. pr. Umans'kogo derzh. ped. un-tu imeni Pavla Tychyny. Uman' : PP Zhovtyj O.O., 2012. Vol. 6. Part 3. P. 57-62.

8. Platonov K. K. Struktura i rozvitok osobistosti [Structure and development of personality]. Moscow: Nauka, 1986. 255 p.

9. Shcholokova O. Mistec'ka osvita u vimirah suchasnosti : problemi teorii i praktiki: monografija, [Art education in the dimensions of the present: problems of theory and practice: monograph.] Dnipropetrovsk, 2014. 301 p.

10. Shcholokova O. P. Hudozhn'o-estetichne vihovannja shkoljariv zasobami svitovö̈ hudozhn'oï kul'turi. [Artistic and aesthetic education of students by means of world art culture.] Kyiv: UDPU, 1993.

11. Chen Kai, Shcholokova Olga. Methodological basis of the future musicianseducators performance-educational activity. Intellectual Archive. - Toronto: Shiny World Corp. (Canada). 2018. (May/June). Vol. 7. No. 3. PP. 94-104.

12. Pet'ko Lyudmila. The development of student youth aesthetic culture on professional direction // Topical issues of contemporary science: Collection of scientific articles. - C.E.I.M., Valencia, Venezuela, 2017. P. 188-192.

13. Shcholokova O. P. Art and pedagogical designing as a means of improvement of music teacher's professional preparing // Economics, management, law: socio-economical aspects of development: Collection of scientific articles. Volum 2. Edizioni Magi. Roma, Italy. 2016. P. 265-268.

Translation of the Title, Abstract and References to the Author's Language УДК 371.13:78

Ван Цізі. Специфіка музично-педагогічної підготовки майбутнього вчителя музики до роботи з інструментальним ансамблем духових інструментів.

У дослідженні здійснено пошук нових шляхів удосконалення керування ансамблевими колективами та формування готовності майбутнього керівника до навчально-виховного прочесу. Готовність студентів до професійної діяльності розглядається як складне особистісне утворення. Воно охоплює комплекс педагогічних впливів, спрямованих на різні сторони індивідуальної діяльності. Вони включають психічні процеси та емоційно-вольові реакції, щуо регулюють ступінь активності людини, мотиви ї̈ поведінки; усвідомлення їх створює сприятливі умови для ефективного формування стану «готовності». Від рівня сформованості в студентів організаторських умінь залежатимуть у майбутньому художньо-творчі і педагогічні результати, щуо має для керівника ансамблевого колективу виняткове значення. Щоб виконати репетиційне завдання, керівник повинен здійснити значну попередню організаційну роботу. Аналіз такої організаторської діяльності дав змогу виділити такі напрямки, як: педагогічний, художньо-виконавський, образно-змістовний та технічний.

Ключові слова: вчитель музики, музично-педагогічна підготовка, ансамбль, духові інструменти. 


\section{Література}

1. Дурай-Новакова К. И. Формування професійної готовності студентів до педагогічної діяльності: автореф. дис. на здобуття наук. ступеня канд. пед. наук: 13.00 .01 . Москва, 1983. 24 с.

2. Каргин А. С. Виховна робота в самодіяльному виховному колективі. Москва: Просвещение, 1984. 224 с.

3. Кондрашова Л. В. Теоретические основы воспитания нравственнопсихологической готовности студентов педагогического института к профессиональной деятельности : дис. ... д-ра пед. наук: 13.00.01. Москва, 1989. 363 с.

4. Крутецкий В. А. Психология математических способностей. Москва, 1988.

5. Левитов Н. Д. О психологических состояниях человека. Москва, 1964. 344 с.

6. Петько Л. В. Формування професійно орієнтованого іншомовного навчального середовища в умовах університету для студентів спеціальності «Музичне мистецтво» (на прикладі вірша Мері Ховітт «Павук і Муха»). Наукові записки Бердянського держ. пед. ун-ту. Педагогічні науки: зб. наук. пр. Вип. 1. Бердянськ: ФО-П Ткачук O.B., 2016. C. 184-190.

7. Петько Л.В. Шляхи формування іншомовної соціокультурної компетенції студентів мистецьких спеціальностей ВН3 у процесі фахової підготовки. Проблеми підготовки сучасного вчителя : зб. наук. праць Уманського держ. пед. ун-ту імені Павла Тичини / Побірченко Н. С. (гол. ред.). Умань : ПП Жовтий О. О., 2012. Вип. 6. Ч. 3. С. $57-62$.

8. Платонов К. К. Структура і розвиток особистості. Москва: Наука, 1986. 255 с.

9. Щолокова О. Мистецька освіта у вимірах сучасності : проблеми теорії і практики: монографія. - Дніпропетровськ, 2014. 301 с.

10. Щолокова О. П. Художньо-естетичне виховання школярів засобами світової художньої культури. - Київ: УДПУ, 1993.

11. Chen Kai, Shcholokova Olga. Methodological basis of the future musicians educators performance-educational activity. Intellectual Archive. - Toronto: Shiny World Corp. (Canada). 2018. (May/June). Vol. 7. No. 3. PP. 94-104.

12. Pet'ko Lyudmila. The development of student youth aesthetic culture on professional direction // Topical issues of contemporary science: Collection of scientific articles. - C.E.I.M., Valencia, Venezuela, 2017. P. 188-192.

13. Shcholokova O.P. Art and pedagogical designing as a means of improvement of music teacher's professional preparing // Economics, management, law: socio-economical aspects of development: Collection of scientific articles. Volum 2. Edizioni Magi. Roma, Italy. 2016. P. 265-268. 